DOI: http://dx.doi.org/10.18203/2320-1770.ijrcog20180900

Original Research Article

\title{
The effect of seasonal variation on the delivery rate: a retrospective study
}

\author{
Reena Pal*, Nikita Gandotra
}

Department of Obstetrics and Gynecology, Government Doon Medical College, Dehradun, Uttarakhand, India

Received: 09 January 2018

Accepted: 03 February 2018

\section{*Correspondence:}

Dr. Reena Pal,

E-mail: Pal.reena49@gmail.com

Copyright: (C) the author(s), publisher and licensee Medip Academy. This is an open-access article distributed under the terms of the Creative Commons Attribution Non-Commercial License, which permits unrestricted non-commercial use, distribution, and reproduction in any medium, provided the original work is properly cited.

\begin{abstract}
Background: We are living in a second most populated country in the world where many social, cultural and ecological processes and events occur regularly every year. These seasonal processes influence many vital rates including birth rates. The objective of this study was to assess the effect of seasonal variation on the delivery rate in tertiary care centre.

Methods: A retrospective descriptive study carried out in Government Doon Medical College Dehradun. We extracted total number of delivery over five years period from hospital records (2012-2016) and analyzed the figures for monthly variation in delivery rates. This was repeated for a standardized 30-day month and the findings compared. Results: The total number of deliveries during the study period were 43,892 with an average of 3,657 deliveries per month. The highest rate of delivery was in the August month and lowest one was in the month of April. The monthly distribution of delivery rate also showed sinusoidal pattern.

Conclusions: There is significant seasonal variation in monthly distribution of delivery rate. There are maximum conception rates are in winter season and minimum conception is in summer season. These findings will prove valuable in health system planning and in the interpretation of seasonal variations in other reproductive parameters.
\end{abstract}

Keywords: Delivery rate, Monthly variation, Seasonal variation

\section{INTRODUCTION}

We are living in a second most populated country in the world where many social, cultural and ecological processes and events occur regularly every year. These seasonal processes influence many vital rates including birth rates. According to Dorelien, births occur throughout the year, but there are groups of months with higher frequencies of births than one would expect by chance alone if the distribution was uniform. Despite the cyclical pattern in the human female reproductive system, humans have the potential of year-round reproduction and human societies have experienced marked seasonal variations in conceptions and births due to the prevailing patterns of economic and social life, often dictated by the seasons or by religious prohibitions. ${ }^{1}$ There were many studies published in literature related to the seasonal effect on the rate of ectopic pregnancy, spontaneous abortion, preeclampsia and eclampsia. ${ }^{2-5}$ Etard et al also reported a seasonal variation in direct obstetric mortality in rural Senegal, although the seasonal variation was statistically insignificant. ${ }^{6}$ However many of these studies had no reference to seasonal variation in the delivery rate, as a possible variable that may have resulted in an apparent seasonal difference in the incidence of these conditions.

The reasons for this seasonality of birth rates is unknown but many hypotheses have been postulated like seasonality of marriages, changes in frequency of sexual 
intercourse due to differences in availability of leisure time, changes in weather conditions and seasonality of biological chances of conception. Among the cultural factors, seasonality in marriages affects the rate of conception. In modern societies, however, it is likely that the probability of conception depends more on the choice of the time of pregnancy than on climate or duration of marriage. $^{7-10}$

This study aims to review the monthly distribution of deliveries which approximately reflects the monthly distribution of conception, as each delivery reflects a conception that occurred about nine months earlier. The knowledge of particular seasonal variation in conception and delivery will be important in various aspects of health system planning, especially those concerning the reproductive health issues.

\section{METHODS}

A retrospective descriptive study was carried out in the department of obstetrics and gynaecology, Government Doon Medical College, Dehradun, a tertiary care centre where all referral obstetric cases from periphery are being managed with annual delivery ranges from 3000-4000. The total number of deliveries over five years from the hospital record extracted. We included all types of deliveries like vaginal or caesarean, preterm or post term and with or without complications. We excluded the abortions and deliveries from outside the hospital.

The total number of deliveries from the hospital records for over five-year period from January 2012 to December 2016 was extracted, tabulated and analyzed. The monthly delivery rate over five years standardized to a uniform 30-day month, to eliminate the disparity that may result from the differences in the number of days in the various months of the year. Percentage of monthly delivery rate over five years analysed and compared.

\section{RESULTS}

The total number of deliveries during the study period over five years from January 2012 to December 2016, were 43,892 with an average of 3,657 deliveries per month. The range of average monthly delivery were from 2923 to 4102 with lowest in April and highest in August.

There was persisting lowest monthly delivery rate in the month of April in 2012, 2015 and 2016 and persisting highest monthly delivery rate in the month of August in 2012, 2014 and 2016 (Table 1). The monthly distribution of delivery showed highest peak of delivery rate in August month with 9.4 percent of average annual delivery and lowest in the month of April with 6.7 percent of average annual delivery. Almost 36 percent of annual delivery occurred in the month of July, August, September and October (Table 2). The percentage distribution of annual delivery plotted in graph which showed slight sinusoidal pattern in the monthly distribution graph with two peak one peak in January and February, another one is in August and September and dip in the month of April and May (Table 1).

Table 1: Standardized monthly distribution of total deliveries (Number of deliveries standardized to a 30 day month).

\begin{tabular}{|lllllll|}
\hline & 2012 & 2013 & 2014 & 2015 & 2016 & Total \\
\hline January & 619 & 711 & 559 & 780 & 813 & 3482 \\
\hline Feb & 725 & 802 & 663 & 747 & 725 & 3662 \\
\hline March & 855 & 835 & 661 & 638 & 669 & 3658 \\
\hline April & 425 & 630 & 699 & 563 & 606 & 2923 \\
\hline May & 588 & 628 & 716 & 674 & 645 & 3251 \\
\hline June & 576 & 664 & 657 & 655 & 614 & 3166 \\
\hline July & 759 & 784 & 746 & 776 & 714 & 3779 \\
\hline August & 862 & 839 & 833 & 745 & 823 & 4102 \\
\hline September & 793 & 846 & 797 & 635 & 748 & 3819 \\
\hline October & 745 & 844 & 783 & 784 & 735 & 3891 \\
\hline November & 752 & 822 & 771 & 746 & 767 & 3858 \\
\hline December & 676 & 722 & 737 & 749 & 768 & 3652 \\
\hline
\end{tabular}

Table 2: Percentage distribution of average annual delivery

\begin{tabular}{|lll|}
\hline Months & $\begin{array}{l}\text { Standardized no. } \\
\text { of delivery }\end{array}$ & $\begin{array}{l}\text { Percentage of } \\
\text { annual delivery }\end{array}$ \\
\hline January & 3482 & 8.0 \\
\hline February & 3662 & 8.44 \\
\hline March & 3658 & 8.43 \\
\hline April & 2923 & 6.7 \\
\hline May & 3251 & 7.5 \\
\hline June & 3166 & 7.3 \\
\hline July & 3779 & 8.9 \\
\hline August & 4102 & 9.4 \\
\hline September & 3819 & 8.8 \\
\hline October & 3891 & 8.9 \\
\hline November & 3858 & 8.8 \\
\hline December & 3652 & 8.4 \\
\hline
\end{tabular}

\section{DISCUSSION}

This retrospective descriptive study shows the highest birth rate in the month of August and lowest one is in the month of April. The study also depicts the sinusoidal pattern with two peaks one in the month of February and March another on in the august to September. It shows the highest month of conception is highest in November and lowest in June. There is significant seasonal variation in the birth rate as various studies had described in literature. ${ }^{11,12}$ Present study shows similar result as Yadava et al, working in India, reported the maximum indices of deliveries in the months of August to October and lowest from April to June. ${ }^{13}$ Over the past 50 years the annual pattern of birth in the United States has been characterized by a peak during August-September and a trough during April-May. ${ }^{14,15}$ National vital statistics report of the United States, also reported that births peak historically in August and reach a nadir in February. ${ }^{16}$ These results indicate that the maximum conception rates 
is in winter season and minimum conception is in summer. Animal and human studies also suggest that high temperatures interfere with spermatogenesis and lower sperm quality could reduce conceptions in the summer, leading to fewer spring births. ${ }^{17,18}$ The peak in birth rate in late summer-early fall may result from increased coital frequency during the winter season. But another study in Nigeria showed a sinusoidal pattern with peak delivery rates in April-May and October and lowest rates in July-August and December. ${ }^{19}$ Photoperiodicity, may also play a role in places with large seasonal variations in day length. ${ }^{20}$

So apart from other factors, different geographical locations will experience different months of peak and nadir in the number of deliveries, as a result of differences in altitudes and climatic conditions. ${ }^{2,21}$

\section{CONCLUSION}

The study shows significant impact of seasonal variation on the birth rate, maximum rate of conception during winters. In health and health-related issues this seasonal variations of birth rates play a great role in understanding the variables that affect the various events. Understanding the variation in conception and delivery rates is of immense value in time-assisted reproductive procedures, in other issues relating to reproductive care, and when planning for a more efficient service delivery.

\section{Funding: No funding sources}

Conflict of interest: None declared

Ethical approval: The study was approved by the Institutional Ethics Committee

\section{REFERENCES}

1. Dorélien AM. A time to be born: birth seasonality in sub-Saharan Africa. University of Michigan Population Studies Center Research Report Series Report. 2013;13(785):1-61.

2. Eskandar M, Archibong E, Sadek A, Sobande A. Ectopic pregnancy and seasonal variation: a retrospective study from the south western region of Saudi Arabia. Bahrain Med Bull. 2002;24:63-5.

3. Goldenberg M, Bider D, Seidman DS, Lipitz S, Mashiach S, Oelsner G. Seasonal pattern in tubal pregnancy. Gynecol Obstet Invest. 1993;35:149-51.

4. Warren CW, Gld J, Tyler CW, Smith JC, Allen L. Seasonal variation in spontaneous abortions. Am J Public Health. 1980;70:1297-9.

5. Okafor UV, Efetie RE, Ekumankama O. Eclampsia and seasonal variation in the tropics: a study in Nigeria. Pan Afr Med J. 2009;2:7.
6. Etard JF, Kodio B, Ronsmans C. Seasonal variation in direct obstetric mortality in rural Senegal: role of malaria? Am J Trop Med Hyg. 2003;68:503-4.

7. Ayani O. Seasonal variation of birth in rural Southwestern Nigeria. Int J Epidemiol. 1986;15:916.

8. Mathers CD, Harris RS. Seasonal distribution of births in Australia. Int J Epidemiol. 1983;12:326-31.

9. Halil SS. The seasonality of births in Canada. J Biosoc Sci. 1989;21:321-7.

10. Erhardat CL, Nelson FG, Pakter J. Seasonal patterns of conception in New York City. Am J Public Health. 1971;61:2246-58.

11. Becker S. Seasonal patterns of births and conception throughout the world. Adv Exp Med Biol. 1991;286:59-72.

12. Roenneberg T, Aschof J. Annual rhythm of human reproduction: I. Biology, sociology, or both? J Biol Rhythms. 1990;5(3):195-216.

13. Yadava KN, Dube D, Marwah SM. A study of seasonal trends in delivery and medical termination of pregnancy. J Obst Gynaecol India. 1979;29:256-7.

14. Lam DA, Miron JA. Global patterns of seasonal variation in human fertility. Ann N Y Acad Sci. 1994;709:9-28.

15. Lam DA, Miron JA. The effects of temperature on human fertility. Demograph. 1996;33(3):291-305.

16. Martin JA, Hamilton BE, Ventura SJ, Menacker F, Park MM. Births: final data for 2000. National vital statistics report. Hyattsville, Maryland: National Center for Health Statistics. 2002;50:8,45.

17. Levine RJ. Seasonal variation of semen quality and fertility. Scand J Work Environ Health. 1999;25(1):34-7.

18. Thonneau P, Bujan L, Multigner L, Mieusset R. Occupational heat exposure and male fertility: a review. Hum Reprod. 1998;13(8):2122-5.

19. Enabudoso EJ, Okpighe AC, Gharoro EP, Okpere EE. Delivery rate in Benin City, Nigeria: are there seasonal variations?. Nigerian J Clin Pract. 2011;14(2):129-31.

20. Bronson FH. Are humans seasonally photoperiodic? J Biol Rhythms. 2004;19(3):180-92.

21. Paonnenberg T, Aschoff J. Annual rhythms of human reproduction and environmental correlations. J Biol Rhythms. 1990;5:217-39.

Cite this article as: Pal R, Gandotra N. The effect of seasonal variation on the delivery rate: a retrospective study. Int J Reprod Contracept Obstet Gynecol 2018;7:1101-3. 